\title{
Scale Effects of STATSGO and SSURGO on Flow and Water Quality Predictions
}

\author{
Prasanna H. Gowda ${ }^{{ }^{*}}$, David J. Mulla ${ }^{2}$, Vinay Nangia ${ }^{3}$, Srinivasulu $\mathrm{Ale}^{4}$ \\ ${ }^{1}$ USDA-ARS Conservation and Production Research Laboratory, Bushland, USA \\ ${ }^{2}$ Department of Soil, Water and Climate, University of Minnesota, St. Paul, USA \\ ${ }^{3}$ International Center for Agricultural Research in Dry Areas, Amman, Jordan \\ ${ }^{4}$ Texas A\&M AgriLife Research, Vernon, USA \\ Email: Prasanna.Gowda@ars.usda.gov
}

Received December 2, 2012; revised January 1, 2013; accepted January 10, 2013

\begin{abstract}
Soil information is one of the crucial inputs needed to assess the impacts of existing and alternative agricultural management practices on water quality. Therefore, it is important to understand the effects of spatial scale at which soil databases are developed on water quality evaluations. In the United States, STATSGO (State Soils Geographic) and SSURGO (Soil Survey Geographic) are the most commonly available soil databases. The purpose of this paper was to quantify the effect of scale by employing STATSGO $(1: 250,000)$ and SSURGO $(1: 24,000)$ soil databases in predicting and comparing flow, sediment, nitrate and phosphorus losses for High Island Creek. This watershed is predominately agricultural and located in south-central Minnesota. The ADAPT (Agricultural Drainage and Pesticide Transport), model was calibrated for flow, sediment, nitrate and phosphorus losses over two years (2001-2002) using STATSGO and SSURGO soil databases. Then the calibrated model was used to evaluate alternative tillage and fertilizer management practices such as adoption of conservation tillage, and rate, timing and method of $\mathrm{N}$ - and P-fertilizer applications. Statistical comparison of calibration results with observed data indicated excellent agreement for both soil databases (STATSGO with $\mathrm{r}^{2}$ of $0.95,0.97,0.77$ and 0.92 and SSURGO with $\mathrm{r}^{2}$ of $0.90,0.97,0.82$ and 0.99 for flow, sediment, nitrate and phosphorus losses, respectively). However, STATSGO based predictions of annual nitrate-N losses were consistently greater than those with SSURGO database and vice-versa for predicted annual phosphorus losses for the alternative management practice that were evaluated.
\end{abstract}

Keywords: Total Maximum Daily Loads; Watershed Management; Agricultural Best Management Practices; ADAPT

\section{Introduction}

Nonpoint source pollution from crop land is a widespread problem in North America. Concerns typically include sediment, nitrogen and phosphorus, as well as herbicides and pathogen export from croplands. Researchers and watershed managers have been monitoring and/or modeling the transport and fate of agricultural pollutants at different spatial scales. Their aim is to describe the processes and pathways that control the concentration and load of nutrients leaving the source area in response to various factors such as climate, soil, or landscape properties, and management alternatives. In contrast, agency leaders and policy makers are typically concerned about decadal or centennial regional trends in water quality at the scale of watersheds, river basins, counties, provinces, states, countries, and continents. They are typically interested in monitoring and/or modeling regional trends in water quality, identifying the

"Corresponding author. sources of pollution and level of impairment, and developing goals and strategies for restoring good water quality. Accordingly, model users are deriving input data at a spatial resolution intuitively suitable for the intended use of the modeling outcomes. Soil information is one of the crucial inputs needed to assess impacts of existing and alternative agricultural management practices on water quality [1-5]. The Natural Resources Conservation Agency (NRCS) has developed two digital soil databases, namely, STATSGO (STATe Soils GeOgraphic; 1: 250,000 scale) and SSURGO (Soil Survey Geographic; $1: 12,000$ to $1: 63,360$ ), which can be used to derive soil input data needed for water quality simulation. The amount of time and resources needed to use them varies significantly based on which soil database is used. The smallest soil map unit represented in STATSGO is about 625.1 ha, whereas it is about 2 ha in the SSURGO database.

Mednick [2] studied the effects of spatial resolution (STATSGO vs. SSURGO) on runoff across Wisconsin 
using a synthetic rainfall dataset and concluded that STATSGO-based estimates under predicted the impact of rainfall intensity. Anderson and others [3] concluded that better representation of the basin and improvement in the hydrologic simulation can be achieved with finer scale SSURGO database. Geza and McCray [4] reported no significant improvements in the hydrologic simulation when finer resolution SSRUGO database was used. However, little is known about the effects of spatial scale on water quality when soil input is derived at different spatial resolution. This study attempts to quantify the effects of spatial resolution of two soil databases on water quality.

The main objective of this study was to determine if there are significant differences between simulated water quality outcomes when using the SSURGO versus the STATSGO soil databases. This was achieved by 1) calibrating a spatial-process model that uses the ADAPT (Agricultural Drainage and Pesticide Transport) model, a field scale water table management model and GIS to predict flow, sediment, nitrogen and phosphorus losses from a 3856 ha minor agricultural watershed in Sibley County, MN; and 2) applying the calibrated spatialprocess model to determine the sensitivity of sediment, nitrate, and phosphorus losses to various agricultural management practices. Evaluated management practices included changes in the adoption of conservation tillage, rate and timing of $\mathrm{N}$ - and P-fertilizers and method of animal manure applications.

\section{ADAPT Model}

The ADAPT model is a daily time-step field scale water table management model which was developed as an extension of the GLEAMS (Groundwater Loading Effects of Agricultural Management Systems) model [6]. GLEAMS algorithms were augmented with algorithms for subsurface drainage, subsurface irrigation, and deep seepage and related water quality processes to develop the ADAPT model [7]. Other enhancements included adding the [8] potential evapotranspiration method as an alternative to the Ritchie method [9]; modifying the runoff curve number based on daily soil water conditions; adding a Green-Ampt infiltration model; modeling snowmelt; and accounting for macropore flow. A frost depth algorithm developed by [10] was incorporated in the ADAPT model to enhance the model's capability to predict flow during spring and fall months and the updated model was evaluated with Lower Minnesota River Basin flow data $[11,12]$. The ADAPT model gives estimates of pesticides and nutrients in tile drainage, in addition to the normal GLEAMS output. The model has four components: hydrology, erosion, nutrient and pesticide transport. The hydrologic component of the model consists of snow-melt, surface runoff, macropore flow, evapotran- spiration, infiltration, subsurface drainage, sub-irrigation, and deep seepage. Weather data required includes daily values of precipitation, temperature, wind speed, relative humidity, and solar radiation for the duration of simulation. However, the model has the option of generating relative humidity and wind speed data if it is not available. Complete details of the model are presented by [7,13-15]. Gowda and others [16] developed and tested a spatial process model that uses the ADAPT model for predicting flow and nutrient discharges at a watershed scale, and successfully used this model in many water quality studies in Minnesota [17-24].

\section{Materials and Methods}

\subsection{Study Area and Water Quality Data}

The study area comprises of two minor watersheds in the High Island Creek watershed, MN (Figure 1). Since April, 2001 the watershed has been monitored for flow, sediment, nitrogen and phosphorus losses as part of the Clear Water Partnership Program involving the Minnesota Pollution Control Agency and Soil and Water Conservation District of Sibley County. Topography of the watershed is relatively flat, and soils are poorly drained. The Clarion-Nicollet-Canisteo (Typic Hapludolls-Aquic Hapludolls-Typic Haplaquolls) soil association is dominant in the watershed with Webster (Typic Haplaquolls), Harps (Typic Calciaquolls), Okoboji (Cumulic Haplaquolls), and Klossner (Terric Medisaprists) soils occupying the closed depressions. About $70 \%$ of the land uses a corn (Zea Mays L.) and soybean (Glycine Max L.) crop rotation and is tile drained.

Discharges at the outlet of the watershed were measured using a 1-stage measuring device which was connected to a Campbell Scientific Inc. (CSI, Logan, UT)

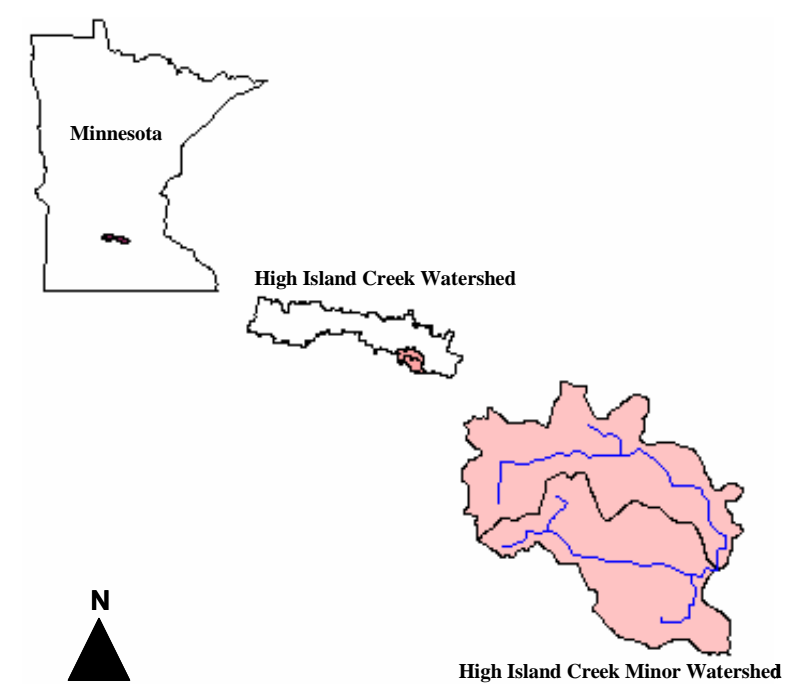

Figure 1. Location of the two High Island Creek minor watersheds in southern Minnesota. 
CR10 data logger. Flow measurements were made every 5-minute. Water samples for water quality were collected automatically with ISCO peristaltic pump samplers (Teledyne Isco, Lincoln, NE). Sampling interval for water quality was based on the rate of change in water level, with more frequent water samples collected during storm events. In addition to automated collection, water quality samples were collected manually on a biweekly basis and after major rainfall events by dipping sterilized glass bottles into stream flow.

\subsection{Model Input}

Climatic data such as daily values of precipitation and mean air temperature used in the water quality simulation were the daily averages of data recorded at four weather stations within the study watershed to account for spatial variability. Other climatic data such as average relative humidity, solar radiation and wind speed were obtained from a weather station located at Jordan, MN, about 50 $\mathrm{km}$ away from the mouth of the High Island Creek watershed.

Soil properties such as the depth of each horizon, particle size distribution, organic matter content, vertical hydraulic conductivity, and soil water release curve for each of the SSURGO and STATSGO soil map units were derived from the Map Unit Use File (MUUF) soil database [25]. Area weighted average soil properties were calculated for each of the STATSGO soil map units. In the summer of 2001, a detailed land use survey was conducted in the High Island Creek watershed to identify crop types at the field level. Aerial photos acquired by the USDA Farm Service Agency were used in conjunction with field survey to develop a land use map for the watershed. This information was stored in GIS format.

Site-specific information on planting and harvesting dates and tillage management practices for 2001 were collected for each field within the High Island Creek watershed. Also, data were collected on timing, method of application, and type of fertilizer or manure through a landowners-operators survey within the watershed as well as from a detailed land owners-operators survey (as part of another watershed project) in the Huelskamp Creek watershed located $20 \mathrm{~km}$ south of the study area. These data were linked to each field in the land use layer attributes. Land use attributes were linked to the tillage and nutrient management data associated with each field.

The spatial process model used in this study requires a set of modeling units known as Transformed Hydrologic Response Units (THRUs) [16] for the study watershed. This involves identifying unique hydrologic response units (HRUs) as a first step, by overlaying available hydrologically sensitive spatial data layers of the area of interest. In this study, unique HRUs were identified by overlaying soil, tillage, and land use layers using Arc
GIS 9.0, a GIS software (ESRI, Inc. Redlands, CA). The unique HRUs with similar watershed characteristics were grouped to form THRUs. Also, a 50-meter buffer strip [26] on each side of the drainage ditches within the watershed was formed to vary sediment delivery ratio based on proximity to nearby streams.

\subsection{Model Calibration}

The spatial process model was calibrated and validated using the water quality data measured at the outlet of the High Island Creek watershed from April to September in 2001 and from April to June in 2002. The calibration of the model for flow was done by adjusting initial depth of water table, soil-water release curve, soil porosity, leaf area index, and depth and hydraulic conductivity of the impeding layer. Sediment delivery ratios of 0.10 and 0.05 were used for THRUs outside and inside of the buffer, respectively. Improvements in the nitrogen and phosphorus loss predictions were made by adjusting initial total nitrogen and phosphorus and nitrate and labile phosphorus levels in the soil horizons. Statistical measures such as mean and Root Mean Square Error (RMSE), coefficient of determination $\left(\mathrm{r}^{2}\right)$ and slope and intercept of the least square regression line between measured and predicted values, and index of agreement (d) [27], were used to evaluate the match between measured and predicted flow and nitrate discharges for the calibration period. The value of $\mathrm{d}$ reflects the degree to which the predicted variation accurately estimates the observed variation. The values of $\mathrm{r}^{2}$, slope, intercept, RMSE, and $\mathrm{d}$ is $1.0,1.0,0.0,0.0$ and 1.0, respectively when there is a perfect agreement between predicted and observed values.

\subsection{Adoption of Conservation Tillage Practices}

The effects of various levels of adoption of conservation tillage practices on water quality in High Island Creek watershed were evaluated by changing the amount of row crop land under conservation tillage. Based on our field and questionnaire surveys in 2001, adoption of conservation tillage with more than $30 \%$ of the topsoil covered with crop residue after planting was adopted on about $24.2 \%$ of the row cropland in the watershed. About $61.5 \%$ of row cropland that adopted conventional tillage had a crop residue level of $0 \%-15 \%$, the remaining $14.3 \%$ of cropland had residue levels of $15 \%-30 \%$. Levels of adoption of conservation tillage used in the simulations include 0.0 (100\% conventional tillage), $24.2 \%$ (existing), and $100 \%$ of the crop land in the watershed. Under the $100 \%$ conventional tillage scenario, two separate simulations were made by changing the crop residue levels on all row crop land to $0 \%-15 \%$ and $15 \%-30 \%$ to quantify the effect of commonly adopted crop residue 
levels on water quality in the watershed.

\subsection{N- and P-Fertilizer Application Rate and Timing}

The Several simulations were made for the period from 2001-2002 to determine the effect of rate and timing of fertilizer application on nitrogen and phosphorus losses. Input parameters used in the simulations for evaluating various practices were the same as those used in the model calibration, unless otherwise stated. Five $\mathrm{N}$ and $\mathrm{P}$ application rates (by changing the existing rate by -20 , $-10,0,+10$, and +20$)$ and in addition, two application timings (fall and spring for $\mathrm{N}$-fertilizer only) were simulated. The use of multiple application rates and timings was to demonstrate the sensitivity of nitrogen and phosphorus losses to variation in precipitation as the application rate and timing changed.

\subsection{Method of Manure Application}

Three scenarios were simulated to evaluate the impact of method of animal manure application on nitrate and phosphorus losses in the High Island Creek watershed. They were: 1) all of the animal manure broadcasted, 2) all of the manure incorporated, and 3) all of the animal manure injected.

\subsection{Scale Effects}

The effects of using two different soil databases of contrasting scales on model predictions were evaluated at two levels by: 1) comparing the statistical performance of the model with the use of SSURGO $(1: 24,000)$ database against that for STATSGO $(1: 250,000)$ database; and 2) comparing the magnitude of predicted water quality loadings under above-mentioned alternative management practices using SSURGO database against that for STATSGO database.

\section{Results and Discussion}

GIS overlay analysis resulted in 224 and 29 THRUs for SSURGO and STATSGO soil databases, respectively. Although the corn-soybean or soybean-corn rotation was followed on about $70 \%$ of the cropland, a greater number of THRUs with the SSURGO database resulted because of its finer spatial resolution. With the STATSGO database, soils in High Island Creek watershed were represented by only one soil map unit (MN046). Corn received a fall application of anhydrous ammonia at 163 or $170 \mathrm{~kg}(\mathrm{~N}) / \mathrm{ha}$ with or without animal manure, respectively (Table 1). About $18 \%$ of the cropland received animal manure, and of this $61.5 \%, 14.2 \%$ and $24.2 \%$ received manure through broadcast applications, incorporation or injection methods, respectively.

\subsection{Model Calibration}

In the calibration phase, attempts were made to minimize the RMSE and achieve $r^{2}$ and $d$ values closest to a value of unity. Table 2 shows an excellent agreement between model predictions and measured flow, sediment, nitrogen and phosphorus losses, with both SSURGO and STATSGO soil data, for the calibration period. Comparison of measured and predicted values of monthly flow shows (Figures 2(a) and (b)) that the magnitude and trend in the predicted monthly flow closely followed the measured data in most of the months. However, the model over predicted measured mean monthly flow $\left(0.37 \mathrm{~m}^{3} / \mathrm{s}\right)$ by $14 \%$ with the STATSGO database (Table 2). Statistical evaluation of measured and predicted flow gave an $\mathrm{r}^{2}$ value of 0.95 , with a slope and intercept of 0.91 and $-0.01 \mathrm{~m}^{3} / \mathrm{s}$, respectively with STATSGO soil data, whereas model predictions with SSURGO soil data gave an $\mathrm{r}^{2}$ value of 0.90 with slope and intercept of 0.99 and $0.01 \mathrm{~m}^{3} / \mathrm{s}$, respectively. The indices of agreement were close to value of 1 (Table 2) and RMSE were about 12 and $15 \%$ of the observed mean monthly flow for STATSGO and SSURGO data, respectively.

Table 1. Baseline $\mathrm{N}$ - and $\mathrm{P}$-fertilizer application rates and timing for corn and soybean crops in the High Island Creek watershed from 2001 to 2002.

\begin{tabular}{ccccc}
\hline \multirow{2}{*}{ Crop } & \multicolumn{4}{c}{ Baseline application rate $(\mathrm{kg} / \mathrm{ha})$} \\
\cline { 2 - 5 } & \multicolumn{2}{c}{ Without animal manure } & With animal manure \\
\cline { 2 - 5 } & $\mathrm{N}$ & $\mathrm{P}$ & $\mathrm{N}$ & $\mathrm{P}$ \\
\hline Corn & 170 & 38 & 163 & 28 \\
Soybean & - & - & - & - \\
\hline
\end{tabular}

Table 2. Model performance statistics for predicted monthly flow, sediment, nitrate and phosphorus discharges in High Island Creek watershed for calibration period.

\begin{tabular}{cccccc}
\hline \multirow{2}{*}{ Statistic } & $\begin{array}{c}\text { Flow } \\
\left(\mathrm{m}^{3} / \mathrm{sec}\right)\end{array}$ & $\begin{array}{c}\text { Sediment } \\
\text { (ton) }\end{array}$ & $\begin{array}{c}\text { Nitrogen } \\
\text { (ton) }\end{array}$ & $\begin{array}{c}\text { Phosphorus } \\
\text { (ton) }\end{array}$ \\
\hline \multirow{3}{*}{ Mean } & Observed & 0.37 & 50.59 & 12.00 & 0.40 \\
& STATSGO & 0.42 & 48.68 & 10.49 & 0.47 \\
& SSURGO & 0.37 & 47.39 & 10.95 & 0.35 \\
\multirow{2}{*}{ RMSE $^{1}$} & STATSGO & 0.12 & 19.92 & 8.69 & 0.21 \\
& SSURGO & 0.15 & 13.71 & 8.28 & 0.10 \\
\multirow{2}{*}{$\mathrm{r}^{2}$} & STATSGO & 0.95 & 0.97 & 0.77 & 0.92 \\
& SSURGO & 0.90 & 0.97 & 0.82 & 0.99 \\
\multirow{2}{*}{ Slope } & STATSGO & 0.91 & 0.84 & 1.34 & 0.94 \\
& SSURGO & 0.99 & 0.95 & 1.45 & 1.12 \\
Intercept & STATSGO & -0.01 & 9.81 & -2.04 & -0.05 \\
& SSURGO & 0.01 & 5.36 & -3.92 & 0.01 \\
$\mathrm{~d}^{1}$ & STATSGO & 0.99 & 0.99 & 0.89 & 0.98 \\
& SSURGO & 0.97 & 0.99 & 0.90 & 0.99 \\
\hline
\end{tabular}

${ }^{1}$ RMSE—Root Mean Square Error; d—index of agreement. 


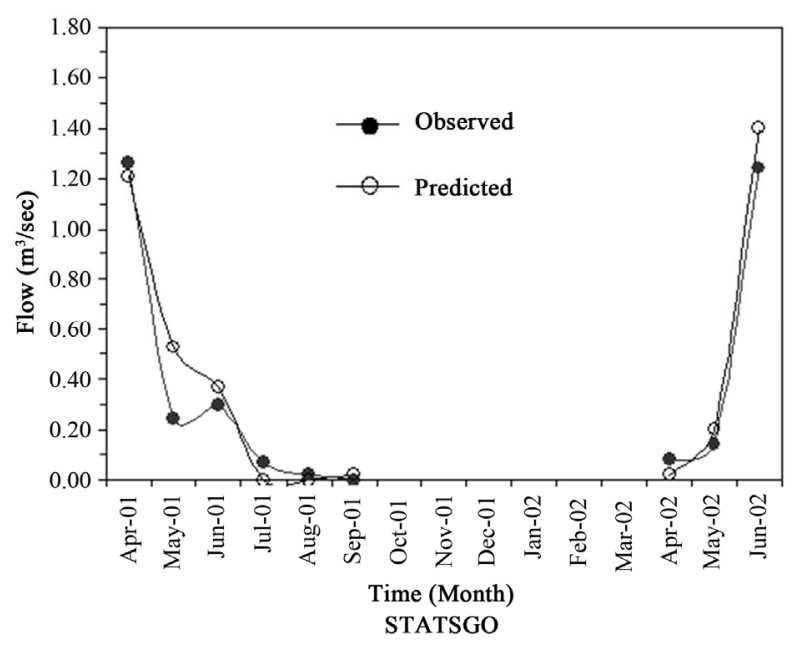

(a)

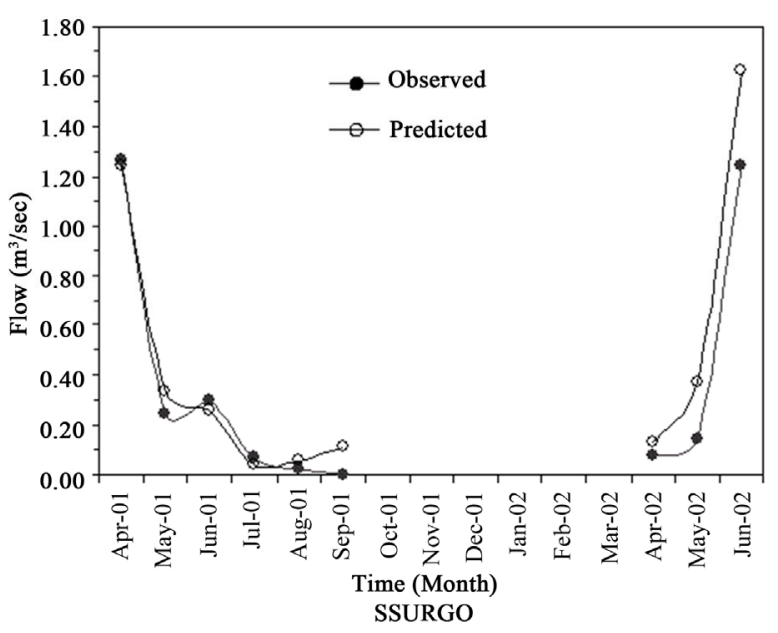

(b)

Figure 2. Comparison of predicted monthly flow against measured data (April 2001-June 2002).

For both STATSGO and SSURGO data, the model predicted $97 \%$ of the variability in sediment losses observed at the outlet of the High Island Creek watershed. The trend in predicted monthly sediment loss (Figures 3(a) and (b)) was similar to that in the measured data, and predicted mean monthly sediment loss (48.7 tons for STATSGO and 47.4 tons for SSURGO) closely matched with measured losses (50.6 tons). The model gave an RMSE equivalent to $19.9 \%$ of the measured mean monthly sediment loss using the STATSGO data, which was $45 \%$ greater than that for SSURGO data.

Predicted monthly nitrate loss was in close agreement with the measured data (Figures 4(a) and (b)). However, the model under predicted mean monthly nitrate (12 tons) by 12.6 and $8.8 \%$ for STATSGO and SSURGO data, respectively (Table 2). The STATSGO-based predictions accounted for about $77 \%$ of the variations in the measured nitrate loadings compared to $82 \%$ with SSURGO- based predictions. The indices of agreement were similar for both databases. Overall, the model seems to predict nitrate losses reasonably well, irrespective of soil database used as input data.

The trend in predicted monthly phosphorus loss (Figures 5(a) and (b)) with both soil databases was similar to that in the measured data. The predicted mean monthly phosphorus loss for STATSGO data were greater than the measured losses ( 0.40 ton) by $17.5 \%$, whereas with SSURGO database, model under predicted phosphorus loss by $12.5 \%$. For phosphorus, the STATSGO-based model predictions explained $92 \%$ of the variability in observed losses at the outlet of the High Island Creek watershed, compared with $99 \%$ for the SSURGO-based predictions. The model gave an RMSE equivalent to 21 and $10 \%$ of the measured mean monthly phosphorus loss for the STATSGO and SSURGO datasets, respectively.

\subsection{Adoption of Conservation Tillage Practices}

Table 3 presents annual sediment and nutrient losses

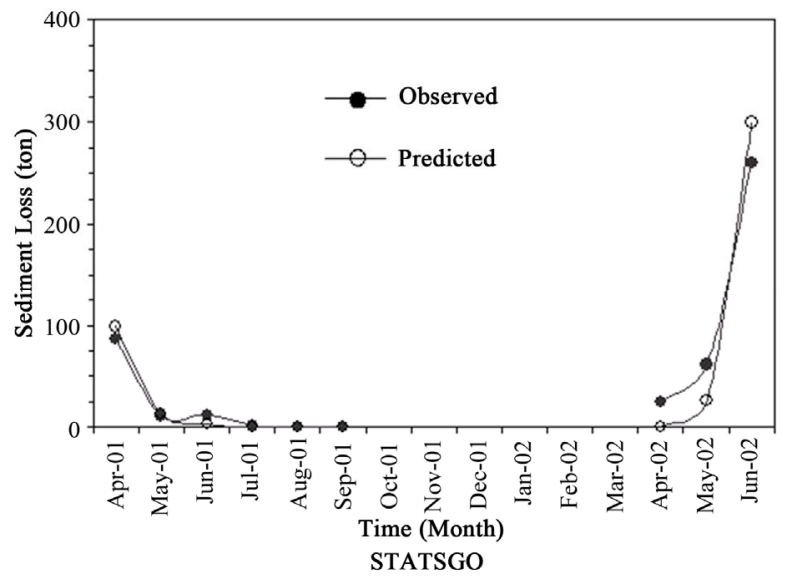

(a)

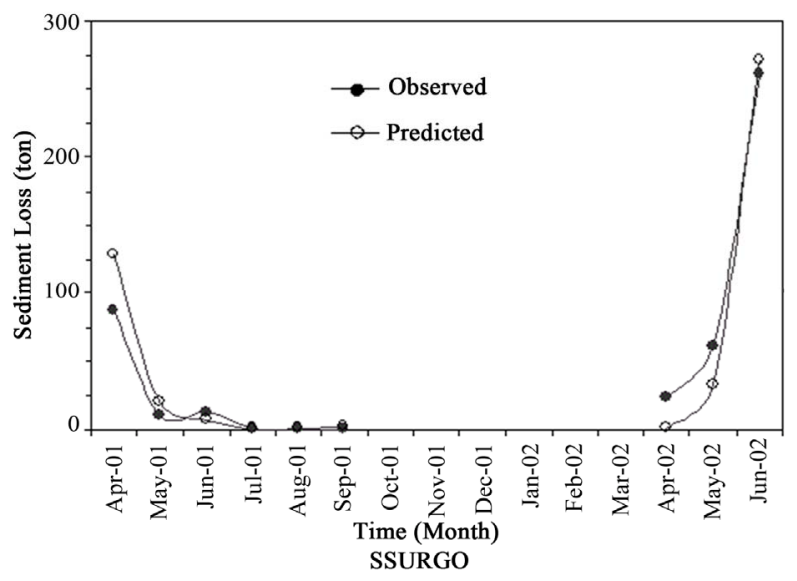

(b)

Figure 3. Comparison of predicted monthly sediment losses against measured data (April 2001-June 2002). 


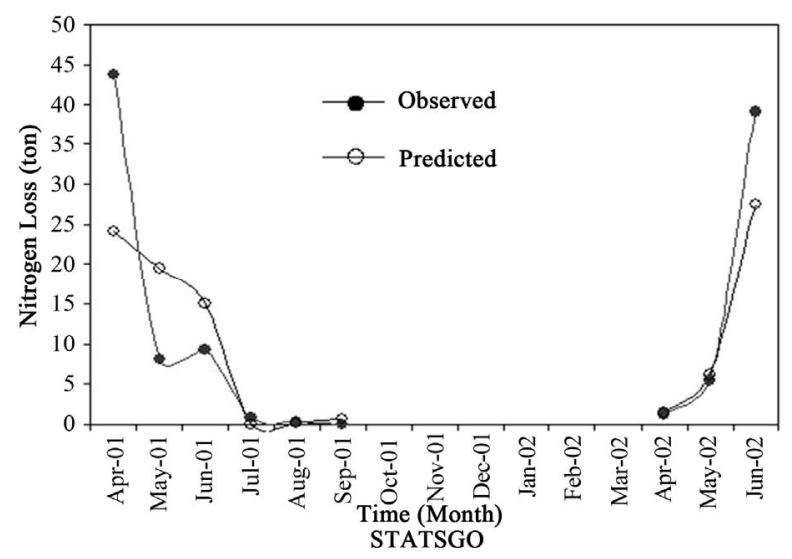

(a)

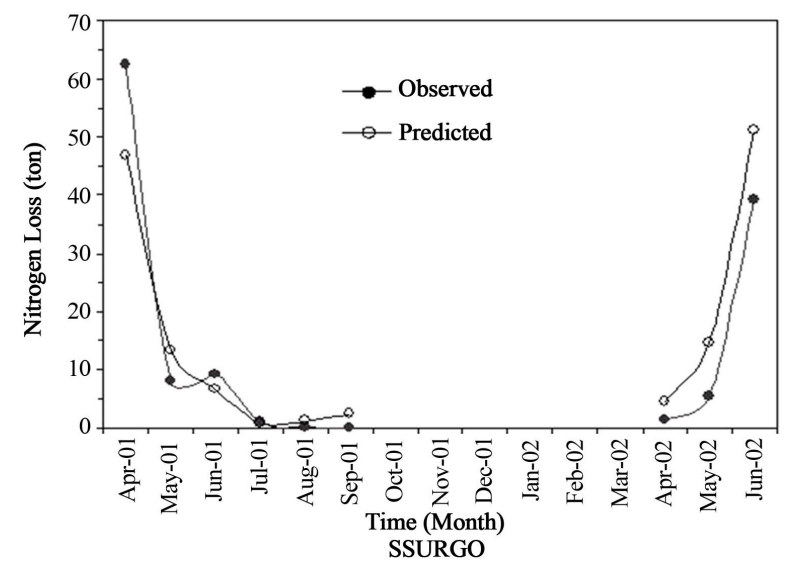

(b)

Figure 4. Comparison of predicted monthly nitrate losses against measured data (April 2001-June 2002).

under existing versus various alternative conservation tillage adoption rates. It also compares SSURGO- and STATSGO-based model predictions to quantify the effect of differences due to spatial scale. With the SSURGO data, annual sediment loss delivered to the mouth of the watershed under existing tillage practices $(24.2 \%$ row cropland under conservation tillage) averaged about 0.06 $\mathrm{Mg} / \mathrm{ha}$. Compared with this, no change was predicted for a scenario in which all cropland had crop residue levels of $0 \%-15 \%$. However, if all cropland had $15 \%$ $30 \%$ crop residue levels, sediment loss would have been reduced by $33.3 \%$ if conservation tillage was adopted on all the crop land. A similar trend was predicted with annual nitrogen and phosphorus losses for the $0 \%-15 \%$ residue cover scenario. The nitrate and phosphate losses increased by about $4.2 \%$ under the $15 \%$ - $30 \%$ residue cover scenario and no change was predicted when entire cropland was converted to conservation tillage With the STATSGO database, the predicted annual sediment, nitrogen and phosphorus losses averaged about $0.06 \mathrm{Mg} / \mathrm{ha}, 14.3 \mathrm{~kg} / \mathrm{ha}$, and $0.62 \mathrm{~kg} / \mathrm{ha}$, respectively, under existing tillage practices (Table 3). Compared

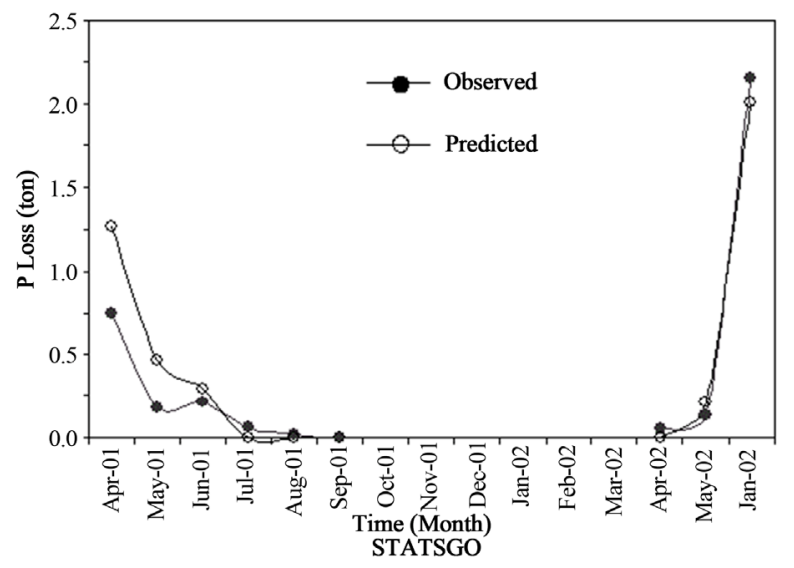

(a)

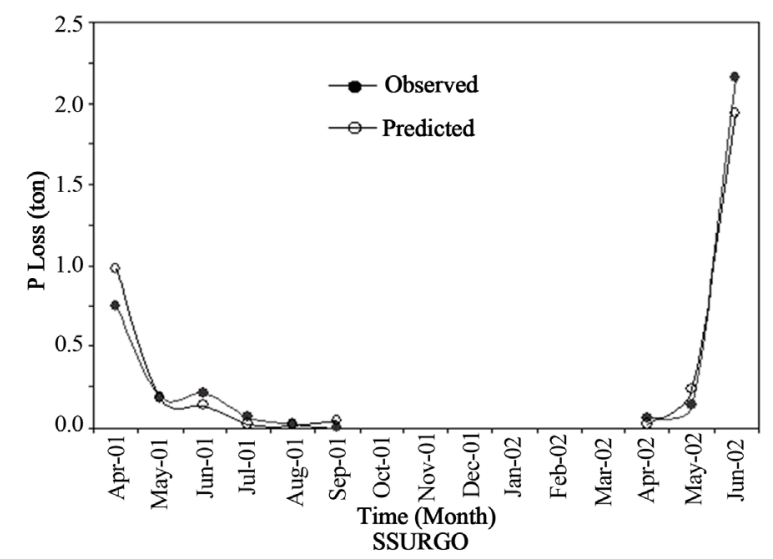

(b)

Figure 5. Comparison of predicted monthly $P$ losses against measured data (April 2001-June 2002).

with this, a $16.6 \%$ increase in sediment losses was predicted when the adoption rate of conservation tillage was decreased from an existing $24.2 \%$ to zero, with a corresponding adoption of $0 \%-15 \%$ crop residue levels on all cropland. However, this change reduced annual nitrogen and phosphorus loss by $3.6 \%$ and $3.2 \%$, respectively. When it was assumed that all the cropland used conservation tillage, a $4.8 \%$ reduction in existing phosphorus losses was possible; however, at the cost of increased nitrogen losses (by $4.6 \%$ ). This is due to the fact that the adoption of conservation tillage practices decreases surface runoff and soil erosion and increases subsurface drainage. With complete adoption of conservation tillage, a $33.3 \%$ reduction in annual sediment loss was predicted. On the other hand, if all cropland had $15 \%$ - 30\% crop residue levels, no change in sediment loss were predicted compared with existing conditions. However, annual nitrogen and phosphorus loss was increased by 4.3 and $4.8 \%$, respectively.

Comparison of model predictions based on SSURGO versus STATSGO data indicated that the trends in predicted annual sediment, nitrogen and phosphorus losses 
Table 3. Predicted annual sediment, nitrogen, and phosphorus losses to existing and various alternative conservation tillage adoption rates in High Island Creek watershed in 2001-2002.

\begin{tabular}{|c|c|c|c|c|c|c|c|c|}
\hline \multirow{3}{*}{ Water Quality Parameter } & \multirow{3}{*}{ Soil Database } & \multirow{3}{*}{$\begin{array}{l}\text { Existing } \\
\text { Loss }^{1}\end{array}$} & \multicolumn{6}{|c|}{$100 \%$ Adoption of Conservation Tillage in Residue Cover Class } \\
\hline & & & \multicolumn{2}{|c|}{$\begin{array}{c}0 \%-15 \% \\
\text { Residue Cover }\end{array}$} & \multicolumn{2}{|c|}{$\begin{array}{c}15 \%-30 \% \\
\text { Residue Cover }\end{array}$} & \multicolumn{2}{|c|}{$\begin{array}{c}>30 \% \\
\text { Residue Cover }\end{array}$} \\
\hline & & & Loss & $\%$ Change & Loss & $\%$ Change & Loss & $\%$ Change \\
\hline \multirow[b]{2}{*}{ SSURGO } & Sediment (ton/ha) & 0.06 & 0.06 & 0.0 & 0.05 & -16.7 & 0.04 & -33.3 \\
\hline & Nitrogen $(\mathrm{kg} / \mathrm{ha})$ & 16.17 & 16.17 & 0.0 & 16.85 & 4.2 & 16.18 & 0.1 \\
\hline \multirow{3}{*}{ STATSGO } & Sediment (ton/ha) & 0.06 & 0.07 & 16.6 & 0.06 & 0.0 & 0.04 & -33.3 \\
\hline & Nitrogen $(\mathrm{kg} / \mathrm{ha})$ & 14.28 & 13.77 & -3.6 & 14.90 & 4.3 & 14.93 & 4.6 \\
\hline & Phosphorus (kg/ha) & 0.62 & 0.60 & -3.2 & 0.65 & 4.8 & 0.59 & -4.8 \\
\hline \multirow{3}{*}{ SSURGO-STATSGO } & Sediment ( $\%$ diff.) & 0.00 & 14.29 & - & 16.67 & - & 0.00 & - \\
\hline & Nitrogen (\% diff.) & -13.23 & -17.43 & - & -13.09 & - & -8.37 & - \\
\hline & Phosphorus (\% diff.) & 24.19 & 21.67 & - & 24.62 & - & 20.34 & - \\
\hline
\end{tabular}

${ }^{1} 61.5 \%, 14.2 \%$ and $24.3 \%$ of the row cropland were in $0 \%-15 \%, 15 \%-30 \%$, and $>30 \%$ crop residue levels, respectively.

were similar when the percentage of crop land under conservation tillage changed from existing to various scenarios. However, the magnitudes of predicted losses were consistently different for nitrogen and phosphorus losses. For example, STATSGO-based predictions of annual nitrogen loss were $8 \%-17 \%$ lower than the SSURGO-based predictions. Similarly, STATSGO-based annual phosphorus loss was $20 \%$ to $25 \%$ greater than phosphorus loss predicted using the SSURGO database. However, with the STATSGO or SSURGO datasets, the model predicted about a $33 \%$ reduction in sediment loss if all row cropland was converted to conservation tillage. This variation was due to the influence of initial nitrogen and phosphorus concentrations in the soil which was varied with soil types in the SSURGO database, whereas they were uniform across the watershed with STATSGO database (as it was only one soil type for the larger scale). Variations in predicted sediment losses with the SSURGO database can be attributed to changes in the water storage capacity as a result of changes in the adoption rate of conservation tillage in the watershed. The ADAPT model uses the Universal Soil Loss Equation (USLE) for estimating soil erosion, and crop management factors used in the model were based on tillage practices.

\subsection{Method of Animal Manure Application}

Annual nitrate loss in the High Island Creek watershed were about $14.3 \mathrm{~kg}(\mathrm{~N}) /$ ha and $16.2 \mathrm{~kg}(\mathrm{~N}) /$ ha with the STATSGO and SSURGO datasets, respectively, under existing conditions (Table 4). Under these conditions, $18 \%$ of the cropland received animal manure, and $61 \%$, $14 \%$ or $24 \%$ of this animal manure was broadcast, incorporated or injected, respectively. Of the scenarios studied with the STATSGO dataset, the greatest annual nitrate loss $[14.4 \mathrm{~kg}(\mathrm{~N}) / \mathrm{ha}]$ was associated with a scenario in which all of the animal manure was incorporated, whereas the greatest annual phosphorus loss $[0.67 \mathrm{~kg}(\mathrm{P}) /$ ha] was associated with a scenario in which all animal manure was applied to the surface. Tile drainage is the main pathway for nitrate transport. Incorporation or injection of animal manure caused more nitrate transport through tile drains than a broadcast application. For phosphorus, sediment in surface runoff is the main transport pathway. Broadcast application of animal manure caused greater $\mathrm{P}$ loss than with incorporation or injection. The greatest reductions in nitrate and phosphorus loss were associated with a scenario in which all of the animal manure was broadcasted or injected, respectively. For phosphorus, annual loss was reduced by $14.5 \%$ with injection versus broadcast. Similar trends were observed with the SSURGO database; however, SSURGO-based predicted nitrate losses were consistently greater than that for STATSGO-based predictions, while SSURGO-based predictions of phosphorus loss was consistently less than from the STATSGO-based predictions.

\section{Conclusion}

A spatial-process model that uses GIS and the ADAPT, a field-scale daily time-step continuous water table management model, was calibrated and validated for flow sediment, nitrogen and phosphorus discharges from the High Island Creek watershed. The model was calibrated using STATSGO and SSURGO soil data. The calibrated model was used to investigate sediment, nitrate and phosphorus loss responses to alternative tillage and nutrient management scenarios such as adoption rate of 
Table 4. Predicted annual sediment, nitrogen, and phosphorus losses to existing and various alternative manure application methods for High Island Creek watershed in 2001-2002.

\begin{tabular}{|c|c|c|c|c|c|}
\hline \multirow{2}{*}{$\begin{array}{l}\text { Water Quality } \\
\text { Parameter }\end{array}$} & \multirow[b]{2}{*}{ Soil Database } & \multicolumn{4}{|c|}{ Percentage Cropland with Animal Manure Application } \\
\hline & & Existing $^{1}$ & $\begin{array}{c}100 \% \text { of Animal Manure } \\
\text { Broadcasted }\end{array}$ & $\begin{array}{l}100 \% \text { of Animal Manure } \\
\text { Incorporated }\end{array}$ & $\begin{array}{c}100 \% \text { of Animal Manure } \\
\text { Injected }\end{array}$ \\
\hline \multirow{3}{*}{ Sediment $(\mathrm{Mg} / \mathrm{ha})$} & STATSGO & 0.06 & 0.06 & 0.06 & 0.06 \\
\hline & SSURGO & 0.06 & 0.06 & 0.06 & 0.06 \\
\hline & $\%$ Change & 0.00 & 0.00 & 0.00 & 0.00 \\
\hline \multirow{3}{*}{ Nitrogen $(\mathrm{kg} / \mathrm{ha})$} & STATSGO & 14.28 & 14.17 & 14.42 & 14.35 \\
\hline & SSURGO & 16.17 & 17.16 & 15.71 & 14.82 \\
\hline & $\%$ Change & -13.23 & -21.11 & -8.95 & -3.27 \\
\hline \multirow{3}{*}{ Phosphorus (kg/ha) } & STATSGO & 0.62 & 0.67 & 0.58 & 0.53 \\
\hline & SSURGO & 0.47 & 0.60 & 0.41 & 0.30 \\
\hline & $\%$ Change & 24.19 & 10.45 & 29.31 & 43.40 \\
\hline
\end{tabular}

${ }^{1}$ Animal manure was broadcasted, incorporated, and injected in $49.5 \%, 21.8 \%$ and $28.7 \%$ of the manured cropland, respectively.

conservation tillage, rate and timing and method of fertilizer applications. For the calibration period, the observed and predicted flow, sediment, nitrogen and phosphorus discharges were in excellent agreement irrespective of the soil database used to derive soil input. However, evaluation of alternative management practices indicated that STATSGO-based nitrate-N loss predictions are consistently greater than those for the SSURGO database and vice-versa for phosphorus loss predictions.

\section{REFERENCES}

[1] M. Di Luzio, J. G. Arnold and R. Srinivasan, "Integration of SSURGO Maps and Soil Parameters within a Geographic Information System and Nonpoint Source Pollution Model System," Journal of Soil and Water Conservation, Vol. 59, No. 4, 2004, pp. 123-133.

[2] A. C. Mednick, "Does Soil Data Resolution Matter? State Soil Geographic Database versus Soil Survey Geographic Database in Rainfall-Runoff Modeling across Wisconsin," Journal of Soil and Water Conservation, Vol. 65, No. 3, 2010, pp. 190-199. doi:10.2489/jswc.65.3.190

[3] R. M. Anderson, V. I. Koren and S. M. Reed, "Using SSURGO Data to Improve Sacramento Model a Priori Parameter Estimates," Journal of Hydrology, Vol. 320, No. 1-2, 2006, pp. 103-116. doi:10.1016/i.jhydrol.2005.07.020

[4] M. Geza and J. E. McCray, "Effects of Soil Data Resolution on SWAT Model Stream Flow and Water Quality Predictions," Journal of Environmental Management, Vol. 88, No. 3, 2008, pp. 393-406. doi:10.1016/j.jenvman.2007.03.016

[5] J. M. Peschel, P. K. Haan and R. E. Lacey, "Influences of Soil Dataset Resolution on Hydrologic Modeling," Journal of the American Water Resources Association, Vol. 42, No. 5. 2006, pp. 1371-1389. doi:10.1111/j.1752-1688.2006.tb05619.x

[6] R. A. Leonard, W. G. Knisel and D. A. Still, "GLEAMS:
Groundwater Loading Effects of Agricultural Management Systems," Transactions of ASAE, Vol. 30, No. 5, 1987, pp. 1403-1418.

[7] E. D. Desmond, A. D. Ward, N. R. Fausey and S. R. Workman, "Comparison of Daily Water Table Depth Prediction by Four Simulation Models," Transactions of ASAE, Vol. 39, No. 1, 1996, pp. 111-118.

[8] J. Doorenbos and W. O. Pruitt, "Guidelines for Predicting Crop Water Requirements," Irrigation and Drainage Paper 24, 1977, FAO United Nations, New York.

[9] J. T. Ritchie, "A Model for Predicting Evaporation for a Row Crop with Incomplete Cover," Water Resources Research, Vol. 8, No. 5, 1972, pp. 1204-1213. doi:10.1029/WR008i005p01204

[10] G. R. Benoit and S. Mostaghimi, "Modeling Frost Depth under Three Tillage Systems," Transactions of ASAE, Vol. 28, No. 5, 1985, pp. 1499-1505.

[11] B. J. Dalzell, "Modeling and Evaluation of Nonpoint Pollution in the Lower Minnesota River Basin," M.S. Thesis, University of Minnesota, St. Paul, 2000, 281 p.

[12] V. Nangia, "Field- and Watershed-Scale Evaluation of Water Quality Trends Due to Changes in Landscape and Management Practices," Ph.D. Dissertation, University of Minnesota, Minneapolis, 2005, $157 \mathrm{p}$.

[13] S. O. Chung, A. D. Ward and C. W. Schalk, "Evaluation of the Hydrologic Component of the ADAPT Water Table Management Model," Transactions of ASAE, Vol. 35, No. 2, 1992, pp. 571-579.

[14] A. D. Ward, E. D. Desmond, N. R. Fausey, T. J. Logan and W. G. Logan, "Development Studies with the ADAPT Water Table Management Model," 15th International Congress on Irrigation and Drainage, The Hague, 1993, pp. 235-245.

[15] P. H. Gowda, D. J. Mulla, E. D. Desmond, A. D. Ward and D. N. Moriasi, "ADAPT: Model Use, Calibration, and Validation," Transactions of ASABE, Vol. 55, No. 4, 2012, pp. 1345-1352. 
[16] P. H. Gowda, A. D. Ward, D. A. White, J. G. Lyon and E. D. Desmond, "The Sensitivity of Stream Flows to Model Input Parameters Used to Define Hydrologic Response Units," Transactions of the ASAE, Vol. 42, No. 2, 1999 , pp. 381-389.

[17] D. M. Davis, P. H. Gowda, D. J. Mulla and G. W. Randall, "Modeling Nitrate Nitrogen Leaching in Response to Nitrogen Fertilizer Rate and Tile Drain Depth or Spacing for Southern Minnesota, USA," Journal of Environmental Quality, Vol. 29, No. 5, 2000, pp. 1568-1581. doi:10.2134/jeq2000.00472425002900050026x

[18] B. J. Dalzell, P. H. Gowda and D. J. Mulla, "Evaluating Feasibility of TMDLs with Alternative Management Practices on an Agricultural Watershed," Journal of the American Water Resources Association, Vol. 40, No. 2, 2004, pp. 533-543. doi:10.1111/j.1752-1688.2004.tb01048.x

[19] K. Updegraff, P. H. Gowda and D. J. Mulla, "Watershed Scale Modeling of the Water Quality Effects of Cropland Conversion to Short Rotation Woody Crops," Renewable Agriculture and Food Systems, Vol. 19, No. 2, 2004, pp. 1-11. doi:10.1079/RAFS200072

[20] D. R. Petrolia and P. H. Gowda, "An Analysis of the Role of Tile-Drained Farmland under Alternative Nitrogen Abatement Policies," Journal of Agricultural and Resource Economics, Vol. 31, No. 3, 2006, pp. 580-594.

[21] P. H. Gowda, B. J. Dalzell and D. J. Mulla, "Model Based Nitrate TMDLs for Two Agricultural Watersheds of Southeastern Minnesota," Journal of the American Water Resources Association, Vol. 43, No. 1, 2007, pp. 1-10. doi:10.1111/j.1752-1688.2007.00020.x
[22] P. H. Gowda, D. J. Mulla and D. B. Jaynes, "Modeling Impact of Timing and Amount of Nitrogen Fertilizer on Water Quality for an Iowan Agricultural Watershed," Agricultural Water Management, Vol. 95, No. 5, 2008, pp. 616-624. doi:10.1016/j.agwat.2008.01.004

[23] V. Nangia, P. H. Gowda, D. J. Mulla and G. R. Sands, "Water Quality Modeling for Impacts of Fertilizer Management Practices on Nitrate-N losses in Tile Drains at the Field-Scale," Journal of Environmental Quality, Vol. 37, No. 2, 2008, pp. 296-307. doi:10.2134/jeq2007.0224

[24] V. Nangia, D. J. Mulla and P. H. Gowda, "Precipitation Changes Impact Stream Discharge, Nitrate-Nitrogen Load More than Agricultural Management Changes," Journal of Environmental Quality, Vol. 39, No. 6, 2010, pp. 2063 2071. doi:10.2134/jeq2010.0105

[25] O. Baumer, P. Kenyon and J. Bettis, "MUUF V2.13 User's Manual," Computer File Which Accompanies the MUUF Software, Natural Resources Conservation Service, 1994.

[26] W. J. Gburek, A. N. Sharpley, L. Heathwaite and G. J. Fohan, "Phosphorus Management at the Watershed Scale: A Modification of the Phosphorus Index," Journal of Environmental Quality, Vol. 29, No. 1, 2000, pp. 130-144. doi:10.2134/jeq2000.00472425002900010017x

[27] D. N. Moriasi, J. G. Arnold, M. W. Van Liew, R. L. Bingner, R. D. Harmel and T. L. Veith, "Model Evaluation Guidelines for Systematic Quantification of Accuracy in Watershed Simulations," Transactions of ASABE, Vol. 50, No. 3, 2007, pp. 885-900. 